\title{
Keefektifan Pemakaian Modul dalam Pembelajaran Reading Comprehension pada Persiapan Tes TOEIC di IKIP Budi Utomo Malang
}

\author{
Maya Rizki Amalyasari \\ Program Studi Pendidikan Bahasa Inggris IKIP Budi Utomo Malang \\ Jalan Citandui 46 Malang \\ saverioenma@gmail.com
}

\begin{abstract}
In International work environment, TOEIC test (Test of English for International Communication) is one of the factors or qualifications dealing with International communication. The result of TOEIC test becomes the reference on how far someone has the ability in mastering English both in Reading Skill and Listening Skill. Whenever someone is able to reach the standard score of TOEIC test, it can be said that he or she is able to communicate both written and orally. Moreover, he or she is able to communicate in English as well. In this research, the researcher focused on the ability of the lecturers of IKIP Budi Utomo Malang in mastering English, especially Reading Comprehension in TOEIC test. Focus on Reading Comprehension Skill was chosen since many lecturers of IKIP Budi Utomo Malang did not reach the standard score of TOEIC test, thus, they did not pass the TOEIC test. Dealing with mastering of Reading Comprehension skill, the researcher implemented Module which contains of Reading Comprehension knowledge and English Grammar knowledge. This Module was then implemented to help the lecturers of IKIP Budi Utomo Malang to understand those materials easily. In this research, the researcher implemented pre-experimental research by giving pre-test and post-test to the lecturers of IKIP Budi Utomo Malang. This pre-test was used to know exactly the ability of the lecturers in mastering Reading Comprehension before they had been given treatment. Then, the post test was used to measure the effectiveness of the implementation of Module in giving understanding and raising lecturers' understanding of Reading Comprehension skill. The implementation of Module was able to raise the lecturers' understanding of Reading Comprehension in TOEIC test, thus, they could reach the standard score in TOEIC test.
\end{abstract}

Keywords: TOEIC test, Reading Comprehension Skill, Module, Learning material

Bahasa inggris adalah bahasa Internasional yang memiliki peran penting dalam era globalisasi.Bahasa inggris menjadi salah satu kriteria penunjang meraih pendidikan yang lebih tinggi dan meraih kesempatan kerja yang lebih luas.Dalam dunia kerja, tes TOEIC (Test of English for International Communication) menjadi salah satu tes penunjang kecakapan dalam komunikasi Internasional.Hasil dari tes TOEIC menjadi acuan seberapa besar kemampuan seseorang dalam dunia kerja, baik dalam kemampuan membaca (Reading Skill) maupun kemampuan mendengarkan (Listening Skill).Jika hasil tes TOEIC di atas rata-rata, maka seseorang dikatakan mampu berkomunikasi dalam Bahasa Inggris baik secara tertulis maupun secara lisan, serta dapat dikatakan sebagai seseorang yang memiliki kemampuan berkomunikasi Internasional yang baik pula.

Berkaitan dengan kemampuan berbahasa Inggris yang dituntut untuk dimiliki oleh setiap tenaga pengajar/dosen di lingkungan IKIP Budi Utomo Malang, dalam penelitian ini, peneliti lebih memfokuskan pada kemampuan membaca (Reading Comprehension).Fokus pada kemampuan membaca (Reading Comprehension) ini dipilih karena masih banyak tenaga pendidik/dosen di lingkungan IKIP Budi Utomo Malang yang memiliki nilai/skot TOEIC di bawah rata-rata. Selain 
itu, peneliti berasumsi bahwa fungsi utama dari proses pembelajaran bahasa kedua (second language) adalah untuk memfasilitasi tenaga pendidik/dosen untuk memiliki kemampuan memahami teks dan struktur kalimat secara gramatikal, sehingga diharapkan pada tahap selanjutnya mereka mampu meraih nilai/skor tes TOEIC di atas rata-rata dan mampu berkomunikasi dengan baik, benar dan gramatikal.

Cahyono (2010) mendefinisikan strategi pembelajarn sebagai langkah spesifik yang dilakukan untuk membuat proses belajar mengajar menjadi lebih mudah, lebih cepat, lebih menyenangkan, lebih mengena, lebih efektif, lebih mudah ditransformasikan ke arah pengembangan kemampuan berkomunikasi. Dalam konteks pemahaman kemampuan membaca (Reading Comprehension) peneliti memakai Module yang berisi berbagai pemahaman tentang membaca (Reading Comprehension) dan tata Bahasa Inggris (English Grammar) untuk lebih memudahkan para tenaga pendidik/dosen IKIP Budi Utomo Malang dalam memahami materi.

\section{METODE}

Dalam penelitian ini,peneliti mengaplikasikan penelitian eksperimental awal dengan memberikan pre-tes dan post-tes kepada para tenaga pendidik/dosen IKIP Budi Utomo Malang. Fungsi dari pre-tes adalah untuk mengetahui kemampuan awal para tenaga pendidik/dosen dalam kemampuan membaca (Reading Comprehension), sedangkan post-tes diberikan untuk mengukur seberapa efektif pemakaian Module dalam memberikan pemahaman dan pengaruh terhadap kemampuan membaca (Reading Comprehension). Pemakaian Module dapat meningkatkan pemahaman membaca (Reading Comprehension) para tenaga pendidik/dosen , sehingga pada akhirnya mereka mampu meraih nilai/skor standar kelulusan dalam tes TOEIC.Selain pre-tes dan post-test, diselipkan pula kuis-kuis yang diberikan setiap satu bulan sekali guna mengasah kemampuan para tenaga pendidik/dosen dalam memahami materi Reading comprehension dan melatih mereka untuk terbiasa menghadapi tes TOEIC.
Metode pelaksanaan pemakaian Module meliputi penggunaan Module dalam pembelajaran membaca (Reading Comprehension) dan rancangan evaluasi. Metode pelaksanaan pemakaian Module dirancang sebagai berikut: (1) Melakukan persiapan dengan menyusun Module yang berisi berbagai pemahaman tentang membaca (Reading Comprehension) dan tata Bahasa Inggris (English Grammar) untuk lebih memudahkan para tenaga pendidik/dosen IKIP Budi Utomo Malang dalam memahami materi (2) Mempersiapkan materi pembelajaran dan soal latihan-latihan yang sesuai dengan konten dalam tes TOEIC (3) Memberikan pelatihan Bahasa Inggris terutama materi persiapan tes TOEIC kepada para tenaga pendidik/dosen dengan menggunakan Module sebagai media ajar (4) Memberikan kuis sebagai media berlatih para tenaga pendidik/dosen untuk mempersiapkan diri menghadapi tes TOEIC

\section{HASIL}

Hasil-hasil yang telah dicapai dalam penelitian ini adalah penyusunan Module dan Pelatihan Bahasa Inggris dengan menggunakan media Module.Module pelatihan Bahasa Inggris ini dibuat hanya mencakup pemahaman membaca (Reading Comprehension).Module ini disusun dalam dua tahap, yaitu Module jilid 1 dan Module jilid 2.Materi yang disajikan dari dua Module yang telah disusun dibuat berdasarkan bahan ajar yang sering dimunculkan dalam tes TOEIC.Di samping itu, Module juga dilengkapi dengan latihan soal yang dapat digunakan oleh tenaga pengajar/dosen sebagai latihan menghadapi tes TOEIC.Selain penyusunan Module, telah dilaksanakan pula pelatihan Bahasa Inggris dengan menggunakan Module yang dilakukan secara rutin setiap minggunya.Kegiatan pelatihan rutin ini mampu meningkatkan kemampuan berbahasa Inggris tenaga pendidik/dosen terutama dalam menghadapi tes TOEIC sebagai persyaratan dalam dunia kerja.

Berkaitan dengan pelaksanaan Pelatihan Bahasa Inggris di atas, telah didapatkan pula nilai/skor pre-tes dan post-tes dari para tenaga pendidik atau dosen di lingkungan IKIP Budi Utomo Malang. Berdasarkan diagram nilai 
pre-tes dan post-tes ujian TOEIC Reading Comprehension yang telah didapat, dapat disimpulkan bahwa distribusi $\mathrm{X}$ tidak normal, sehingga peneliti menganalisis data menggunakan Korelasi Spearman. Selain itu, Korelasi Spearman digunakan karena jumlah sampel yang digunakan dalam penelitian tidak lebih dari 30 sampel.Sampel yang didapat adalah 11 sampel yang merupakan para tenaga pendidik/dosen IKIP Budi Utomo Malang.Besar korelasi yang didapat cukup lemah, yaitu sebesar 20, 87\%. Dari hasil korelasi ini dapat disimpulkan bahwa $\mathrm{H}_{\mathrm{o}}$ (Hipotesis Null) diterima karena korelasinya cukup lemah, tetapi terdapat kenaikan kemampuan para tenaga pendidik/dosen dalam memahami Reading Comprehension sebesar $20,87 \%$. Sebagai kesimpulan, terdapat kenaikan kemampuan memahami Reading Comprehension pada para tenaga pendidik/dosen IKIP Budi Utomo Malang sebesar $20,87 \%$ dan dapat disimpulkan pula bahwa pemakaian Module sebagai media pembelajaran dianggap cukup efektif dan efisien.

\section{PEMBAHASAN}

Hasil penelitian menunjukkan bahwa pemakaian Module dalam pembelajaran Reading Comprehension dalam persiapan tes TOEIC menunjukkan bahwa terdapat kenaikan kemampuan memahami Reading Comprehension pada para tenaga pendidik/dosen IKIP Budi Utomo Malang sebesar 20,87\%. Hal ini dapat disimpulkan bahwa pemakaian Module sebagai media pembelajaran dianggap cukup efektif dan efisien. Pemakaian Module dikatakan efektif dan efisien karena telah merangkul beberapa hal, yang pertama adalah Module berisikan berbagai pemahaman tentang membaca (Reading Comprehension) dan tata Bahasa Inggris (English Grammar) untuk lebih memudahkan para tenaga pendidik/dosen IKIP Budi Utomo Malang dalam memahami materi. Materi dipaparkan mulai dari definisi yang mendetail, rumus yang mudah diingat dan diapliaksikan dalam kalimat atau contoh soal, contoh soal yang paling sering muncul dalam tes TOEIC, dan strategi menghafal yang mudah diingat oleh para tenaga pendidik/dosen. Criteria Module yang seperti ini sangat sesuai untuk para tenaga pendidik/dosen yang bukan dari jurusan Bahasa Inggris dan hanya memiliki bekal pengetahuan Bahasa Inggris terakhir pada jenjang SMA.

Selain itu, Module dikatakan efektif dan efisien karena Module digunakan sebagai media yang dapat memberikan pemahaman yang lebih detail dan mudah diingat karena berisi tentang definisi, rumus, contoh, dan strategi menghafal yang mudah diingat oleh para tenaga pendidik/dosen.Module dipakai agar ketika para tenaga pendidik/dosen lupa akan suatu materi, mereka bisa membuka kembali Module untuk mengerjakan latihanlatihan. Module dianggap lebih efektif karena peneliti tidak perlu menulis di papan tulis (guna efisiensi waktu) dan catatan peserta didik/dosen dapat diselipkan pada Module sehingga mereka tidak khawatir catatan mereka hilang.Kriteria Module yang kedua ini sesuai dengan karakteristik para tenaga pendidik/dosen didominasi oleh mereka yang berusia di atas 35 tahun dan sudah terlalu lama tidak belajar Bahasa Inggris. Pada usia di atas 35 tahun ini, mereka membutuhkan 'treatment' atau perlakuan yang khusus yang lebih mendetail dan berulang-ulang dalam pembelajaran Bahasa Inggris.

Selain kedua hal tersebut di atas, Module juga dapat dijadikan sebagai acuan belajar di rumah ketika tenaga pendidik/ dosen tidak hadir di dalam kelas sehingga mereka tidak ketinggalan materi. Hal ini dikarenakan para tenaga pendidik/dosen di kelas pelatihan Bahasa Inggris hadir cukup tidak konsekuen hadir di dalam kelas, hal ini dikarenakan oleh bentrok dengan jam mengajar atau kesibukan lain yang berkaitan dengan profesi sebagai tenaga pendidik, sehingga jika materi diberikan dengan cara menulis di papan tulis, maka mereka yang tidak hadir akan ketinggalan materi ketika tidak hadir.

\section{KESIMPULAN DAN SARAN}

Dalam dunia kerja, TOEIC (Test of English for International Communication) menjadi salah satu tes penunjang kecakapan dalam komunikasi internasional. Hasil dari test TOEIC menjadi acuan seberapa besar 
kemampuan seseorangdalam berbahasa Inggris baik dalam kemampuan membaca atau (Reading Skill) ataupun mendengarkan (Listening skill).Jika hasil tes TOEIC di atas rata-rata, maka seseorang dikatakan mampu berkomunikasi baik secara tertulis maupun secara lisan, serta dapat dikatakan sebagai seseorang yang memiliki kemampuan berbahasa Inggris atau berkomunikasi Internasional dengan baik.

Fokus pada kemampuan membaca (Reading Comprehension) pada persiapan tes TOEIC ini dipilih karena banyak sekali tenaga pendidik atau dosen di lingkungan IKIP Budi Utomo Malang yang kurang mampu mengerjakan latihan-latihan soal dalam test TOEIC yang berkaitan dengan pamahaman membaca dan tata bahasa Inggris sehingga belum memenuhi standar nilai atau poin kelulusan dalam tes TOEIC. Dalam konteks pemahaman membaca (Reading Comprehension) pemakaian Module yang berisi berbagai pemahaman tentang membaca (Reading Comprehension) dan tata bahasa Inggris atau (English Grammar) diharapkan untuk lebih memudahkan para tenaga pendidik atau dosen IKIP Budi Utomo dalam memahami materi.

Berdasarkan pemakaian Module dalam pemahaman Reading Comprehension dan deskripsi di atas, dapat disimpulkan bahwa hasil yang dicapai meliputi (1) penyusunan materi ajar yang mencakup pembelajaran membaca (Reading Comprehension) untuk persiapan tes TOEIC, (2) penggunaan Module dalam pembelajaran membaca (Reading Comprehension) Module ini telah tercetak dalam 2 Jilid, yaitu ModuleJilid 1 dan Jilid 2, (3) pembekalan pembelajaran Bahasa Inggris kepada para tenaga pendidik/dosen di lingkungan IKIP Budi Utomo Malang dengan menggunakan Module (4) hasil akhir dari pemakaian Module dalam memahami Reading Comprehension pada persiapan tes TOEIC.

Module ini secara berkesinambungan digunakan sebagai media pembelajaran membaca (Reading Comprehension) dalam rangka persiapan menghadapi tes TOEIC bagi para tenaga pendidik/dosen IKIP Budi Utomo Malang. Hasil dari pemakaian Module ini menunjukkan bahwa distribusi $\mathrm{X}$ tidak normal, sehingga peneliti menganalisis data menggunakan Korelasi Spearman. Selain itu, Korelasi Spearman digunakan karena jumlah sampel yang digunakan dalam penelitian tidak lebih dari 30 sampel.Sampel yang didapat hanya 11 sampel dari sekian banyak jumlah tenaga pendidik/dosen IKIP Budi Utomo Malang.Besar korelasi yang didapat cukup lemah, yaitu sebesar 20, 87\%. Dari hasil korelasi ini dapat disimpulkan bahwa $\mathrm{H}_{\mathrm{o}}$ diterima karena korelasinya cukup lemah, tetapi terdapat kenaikan kemampuan para tenaga pendidik/dosen dalam memahami Reading Comprehension sebesar 20,87\%. Sebagai kesimpulan, terdapat kenaikan kemampuan memahami Reading Comprehension pada para tenaga pendidik/dosen IKIP Budi Utomo Malang sebesar 20,87\% dan dapat disimpulkan pula bahwa pemakaian Module sebagai media pembelajaran dianggap cukup efektif.

Dari hasil yang dicapai di atas, maka disarankan untuk lebih mengefektifkan penggunaan Module dalam pembelajaran membaca (Reading Comprehension) sebagai persiapan menghadapi tes TOEIC sehingga para tenaga pendidik/dosen mendapatkan skor/nilai tinggi dalam tes TOEIC. Selain itu, pembelajaran dengan menggunakan Module diharapkan dapat meningkatkan kemampuan para tenaga pendidik/dosen dalam berkomunikasi dalam Bahasa Inggris dengan baik dan gramatikal.

\section{DAFTAR RUJUKAN}

Brown, J.W., Lewis, R.B., Harcleroad, F.F. 1983. AV Instruction: Technology, Media and Methods. (6 ${ }^{\text {th }}$ edition). New York:McGraw-Hill, Inc.

Cahyono, B.Y. 1997. Pengajaran Bahasa Inggris: Teknik, Strategi dan Hasil Penelitian. Malang: IKIP Malang

Gagne, R.M., Briggs, L.J. 1979. Principles of Instructional Design.( $2^{\text {nd }}$ edition). New York: Holt, Rinehart \& Winston

Hardjito.2004. Peran Guru dalam Pemanfaatan Media Pembelajaran Ditinjau dari Perspektif Pendidikan Progresif.Jurnal Tekdonik, 8 (14): 85:107

Heinich, R., Molenda, M. Russel, J.D. \& Smaldino, S.E. 2002. Instructional 
12 Jurnal Paradigma, Volume 22, Nomor 1, Januari-Juni 2016

Media and Technologies for (http://www.umdnj.edu/idsweb/idst5330/ Learning $\left(7^{\text {th }}\right.$ edition). New Jersey: Pearson Education Inc. instructional media.htm, accessed on August 15, 2009)

Reiser, R.A. \& Dick, W. 1996.Instructional Sudjana, N. \& Rivai, A. 2009.Media Planning: A Guide for Teachers. Boston: Allyn and Bacon Pengajaran.Bandung: Sinar Baru Algesindo

Sadiman, A., dkk. 2003. Media Pendidikan. Wager, W. 2001.Instructional Media: Pengertian, Pengembangan dan Chalkboards to Video, (Online), Pemanfaatannya.Jakarta: PT Raja Grafindo Persada (http://ctl.sdsu/guide/9Instructional\%20media.Pdf, accessed on Scanlan, C.L. 2003. Instructional Media: Selection and Use, (Online), 